Vol. 11, No. 1 (Juni 2019)

\title{
Pendidikan Ruhani Dalam Alquran
}

\author{
Subri $^{1 *}$, Achmad Bachtiar ${ }^{2}$ \\ IAIN Syaikh Abdurrahman Siddik Bangka Belitung ${ }^{1}$ \\ SMP Negeri 1 Patumbak $^{2}$ \\ ${ }^{*}$ email: subri@iainsasbabel.ac.id \\ ${ }^{2}$ email: achmadbahtiar3@gmail.com
}

\begin{abstract}
Education is a human need. Therefore, every human being must receive proper education to be able to live as a human being. In this perspective, human beings must be educated to survive in their lives amid tight competition. With the importance of education, Allah has commanded to gain knowledge as someone who has an education and a decent life.

Spiritual education is an effort to purify the soul of various inclinations to purify the soul from various bad tendencies and sins, then decorate it with good deeds and praiseworthy qualities so that it is always submissive and obedient to Allah, and the attainment of the degree of piety, so the realization of morality karimah and feel always watched by Allah Swt.
\end{abstract}

Keywords: Education, Spirituality, Alquran
Artikel Info

Received:

27 Januari 2019

Revised:

19 Maret 2019

Accepted:

28 April 2019

Published:

19 Juni 2019

\begin{abstract}
Abstrak
Pendidikan merupakan kebutuhan manusia. Karena itu, setiap manusia harus menerima pendidikan yang layak untuk bisa hidup sebagai seorang manusia. Dalam perspektif ini, bahwa manusia wajib berpendidikan untuk dapat survive dalam hidupnya ditengah persaingan hidup yang ketat. Dengan sedemikian pentingnya pendidikan, maka Allah Swt memerintahkan untuk menimba ilmu sebagai sebab seseorang memperoleh pendidikan dan kehidupan yang layak.

Pendidikan ruhani merupakan sebuah upaya untuk menyucikan jiwa dari berbagai kecenderungan untuk menyucikan jiwa dari berbagai kecenderungan buruk dan dosa, kemudian menghiasinya dengan amal shalih dan sifatsifat terpuji agar selalu tunduk dan patuh kepada Allah Swt, serta tercapainya derajat ihsan, sehingga terwujudnya akhlak al-karimah dan merasakan selalu diawasi Allah Swt.
\end{abstract}

Kata Kunci : Pendidikan, Ruhani, Alquran 


\section{A. Pendahuluan}

Alquran adalah sumber kehidupan umat Islam dalam berbagai aspek dalam ruang kehidupannya. Menjadikan Alquran sebagai pedoman hidup merupakan sebuah tuntutan bahkan kewajiban bagi umat Islam agar dalam menjani fase-fase kehidupannya dapat berjalan dengan baik, benar dan selamat. Mengapa, karena Alquran al-Karim adalah satu-satunya wahyu yang kekal hingga saat ini. Ia merupakan kitab suci yang tidak pernah tercampur dengan kebathilan dan tidak ada keraguan sedikitpun didalamnya, sebagaimana ditegaskan dalam surat al-Baqarah yaitu,"Kitab (Alquran) ini tidak ada keraguan padanya." (Q.S. al-Baqarah [2]: 2).

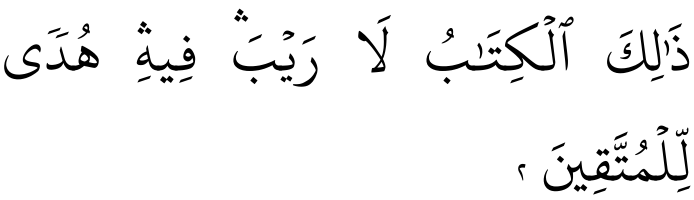

Kemudian pendidikan merupakan wadah dari sebuah proses yang juga wajib dimiliki oleh manusia sebagai lentera dan pedoman bagi kehidupannya agar hidup dapat terbina, terdidik, terarah, benar, layak, dan selamat. Paradigma pendidikan dalam Islam tentunya tidaklah hanya sekedar pada akal dan jasmani saja, akan tetapi terkait juga dengan pembinaan aspek ruhani yang dikuatkan hubungannya dengan Tuhan. Semua ini telah termaktub dalam Alquran, bahwa pendidikan ruhani erat kaitannya dengan hablun minallah ${ }^{l}$, tazkiyatun nafs, ${ }^{2}$ zikir, ${ }^{3}$ ridha, ${ }^{4}$ ikhlas, ${ }^{5}$ shalat, ${ }^{6}$ puasa, ${ }^{7}$ haji ${ }^{8}$ dan lain sebagainya. Melalui tahapan-tahapan shalat, puasa, haji, zikir, ikhlas, tazkiyah, muroqobah dan ridha, inilah kemudian yang harus dilakukan dalam pendidikan ruhani. Dengan tujuan semata-mata untuk mendekatkan diri kepada Allah Swt atau dengan kata lain bahwa pendidikan ruhani kemudian dapat dinyatakan merupakan pendidikan yang mendidik, membina dan membenahi ruhani atau ruh manusia agar semakin lebih mengenal dan semakin dekat hubungannya kepada Allah Swt. Hubungan manusia dengan Allah Swt merupakan prima causa hubunganhubungan yang lain, karena hubungan inilah sejatinya menempati peringkat
${ }^{1}$ QS. Ali Imran: 112
${ }^{2}$ QS. As-Syams: 9
${ }^{3}$ QS. Al-Baqarah: 152
${ }^{4}$ QS. Al-Mujadalah: 22
${ }^{5}$ QS. As-Shaad: 82-83
${ }^{6} \mathrm{QS}$. Al-Baqarah: 3
${ }^{7}$ QS. Al-Baqarah: 183
${ }^{8}$ QS. Al-Hajj: 27-32 
pertama dan diutamakan secara tertib dan teratur dijaga dan dipelihara. "Sebab manusia dengan menjaga hubungannya kepada Allah Swt akan terkendali dan tidak melakukan kejahatan terhadap dirinya, masyarakat dan lingkungan sekitarnya."9

Pemeliharaan hubungan tersebut dapat dilakukan dengan cara diantaranya adalah (1) beriman kepada Allah Swt menurut cara-cara yang diajarkan sesuai dengan wahyu yang diturunkan, (2) beribadah kepada-Nya dengan melaksanakan shalat, mengeluarkan zakat, puasa dan haji bagi yang mampu, (3) bersyukur atas nikmat yang telah diberikan-Nya, (4) bersikap sabar atas ketentuan-Nya, (5) memohon ampun terhadap dosa yang dilakukan dengan cara taubat hanyalah kepada-Nya. Sesungguhnya kebutuhan manusia kepada Allah Swt bersifat abadi, sebagaimana ditegaskan dalam ayat Alquran pada surat al-Anbiya',
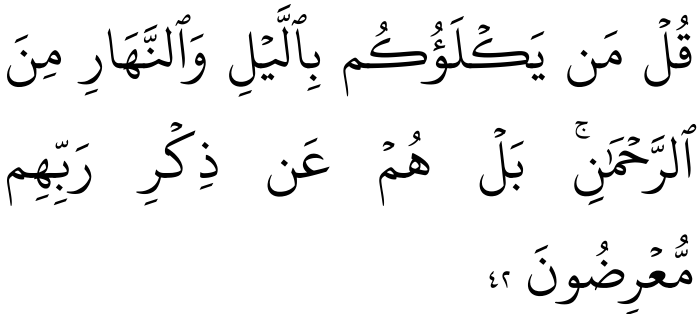

9 Mohammad Daud Ali, Pendidikan Agama Islam, (Jakarta: PT. Raja Grafindo Persada, 1998), h. 368.
"Katakanlah, siapakah yang dapat memelihara kamu di waktu malam dan siang hari selain (Allah) Yang Maha Pemurah, Sebenarnya mereka adalah orang-orang yang berpaling dari mengingat Tuhan mereka." 10

Oleh karenanya kehidupan ruhani akan bahagia jika tetap berpegang teguh kepada tali Allah yaitu Alquran. Ruhani perlu dididik dan dibina, melalui pendidikan ruhani maka tidak ada beban seberat apapun jika melakukannya dengan hati yang sabar, ikhlas, ridha dan tawakkal karena "Allah Swt menurunkan Alquran bukan untuk memberatkan manusia, melainkan agar mereka terbimbing sehingga tidak berat, susah, ragu dan galau dalam melanjutkan kehidupan di dunia ini. Justru Alquran akan membimbing manusia agar bahagia jika dijalankan sesuai dengan tuntunan Alquran, hidup yang benar dan sesuai dengan fitrah manusia karena sesungguhnya Allah Swt maha tahu iradah kemauan manusia hidup." 11

Berangkat dari beberapa penjelasan diatas, maka selain memiliki raga yang sehat atau jasmani yang kuat

${ }^{10}$ Q.S. Al-Anbiya': 42

11 Adam Cholil, Dahsyatnya Alquran, Alquranul Karim Menjadi Petunjuk dan Solusi Bagi Umat Manusia dalam Mengarungi Samudera Kehidupan, (Jakarta: AMP Press, 2014), h. 75 
akan tetapi tidak kalah pentingnya bahwa memiliki jiwa yang sehat atau ruhani yang kuat dan mantab merupakan modal agar kehidupan dapat menjadi bahagia lahir dan bathin. Kebahagiaan tentunya tidak hanya sekedar dilihat dari luar atau fisiknya saja akan tetapi akan lebih penting lagi jika yang memiliki jiwa atau hati atau ruhani tersebut lebih utama harus merasakan kebahagiaan. Maka jiwa, hati dan ruhani perlu di didik, di latih, di bina, dan di arahkan melalui pendidikan dengan kemulyaankemulyaan berupa shalat, zikir, puasa, tazkiyah, muroqobah, dan ridha agar hidup lebih tenang dan damai. Oleh karenanya, berangkat dari aspek inilah kemudian pentingnya pendidikan ruhani yang bersumber dari ajaran Alquran alkarim.

Dalam pembahasan terhadap kajian ini, memiliki tujuan, diantaranya adalah: 1) Untuk mengetahui apa yang dimaksud dengan pendidikan ruhani; 2) Untuk mengetahui dalam Alquran ayatayat yang membahas tentang pendidikan ruhani; 3) Untuk mengetahui bagaimana karakteristik dari pendidikan ruhani dalam Alquran.

\section{B. Pembahasan}

Manusia sebagai ciptaan Allah Swt yang paling sempurna dari makhluk lainnya tentunya memiliki banyak keutamaan-keutamaan. Keutamaan itu diantaranya adalah bahwa manusia memiliki akal untuk berpikir dan hati untuk bertafakkur kemudian berproses dan berimajinasi yang tidak dapat dilakukan oleh makhluk hidup lainnya. Hal inilah kemudian yang membedakan manusia secara signifikan, dimana manusia mengetahui mana yang benar dan salah, mana yang baik dan jelek, dan mana yang bersih dan kotor yang tentunya makhluk lain tidak bisa memberdakannya. Sebagai makhluk Allah yang sempurna pada ciptaan-Nya dengan memiliki berbagai potensi, tidaklah kemudian menjadi sempurna pada keseluruhannya. Akan tetapi potensi-potensi yang ada pada manusia tersebut harus diolah, dilatih dan dididik sehingga terarah, memiliki makna dan dapat bermanfaat atau dimanfaatkan. Potensi yang melekat pada manusia itu kemudian dapat dibagi dua yaitu potensi jasmani dan potensi ruhani. Maka tidak berlebihan kemudian pernyataan Prof. Jalaludin bahwa, "Pada diri manusia sudah ada potensi ruhani atau potensi 


\section{INTIQAD: JURNAL AGAMA DAN PENDIDIKAN ISLAM}

ISSN 1979-9950 (print) || ISSN 2598-0033 (online), http://jurnal.umsu.ac.id/index.php/intiqad DOI: https://doi.org/10.30596/intiqad.v11i1.3195

Vol. 11, No. 1 (Juni 2019)

keagamaan, yaitu berupa dorongan untuk mengabdi kepada sesuatu yang dianggapnya memiliki kekuasaan yang lebih tinggi yaitu sang kholik."12 Kemudian juga pernyataan dari Syahminan, ia menyebutkan bahwa, "potensi agama atau fitrah agama sudah tertanam ke dalam jiwa atau ruh manusia semenjak dari alam arwah, yaitu sewaktu ruh manusia belum ditiupkan Allah Swt ke dalam jasmaninya."13

Oleh karena itu, penting kiranya agar fitrah agama tersebut tetap istiqomah pada diri manusia melalui riyadhah, pembinaan dan pendidikan. Salah satu fitrah agama tersebut yang membuthkan pendidikan adalah aspek ruhani karena ruhani erat kaitannya dengan keyakinan seseorang kepada sang kholik untuk mendekatkan diri kepada-Nya. Maka, lebih lanjut pada makalah ini akan dibahas tentang pendidikan ruhani dalam Alquran.

\section{Pengertian Pendidikan Rohani}

Pendidikan merupakan kebutuhan manusia yang hidup didunia ini agar dapat berinteraksi kepada sesamanya

12 Jalaludin, Teologi Pendidikan, (Jakarta: PT. RajaGrafindo Persada, 2003), h. 35

13 Syahminan Zaini, Hakikat Agama dalam Kehidupan Manusia, (Surabaya: AlIkhlas, 1991), h. 73 dengan baik dan benar. Oleh karenanya, setiap manusia harus menerima dan memiliki pendidikan yang layak untuk bisa hidup sebagai seorang manusia. Dalam perspektif ini, bahwa kemudian manusia wajib berpendidikan untuk dapat survive dalam hidupnya ditengah persaingan hidup yang ketat. Dengan sedemikian pentingnya pendidikan, maka Allah Swt memerintahkan untuk bertafaqquh fid diin atau menimba ilmu sebagai sebab seseorang memperoleh pendidikan dan kehidupan yang layak. Dalam Alquran Allah Swt tegaskan dalam surat at-Taubah yang berbunyi;

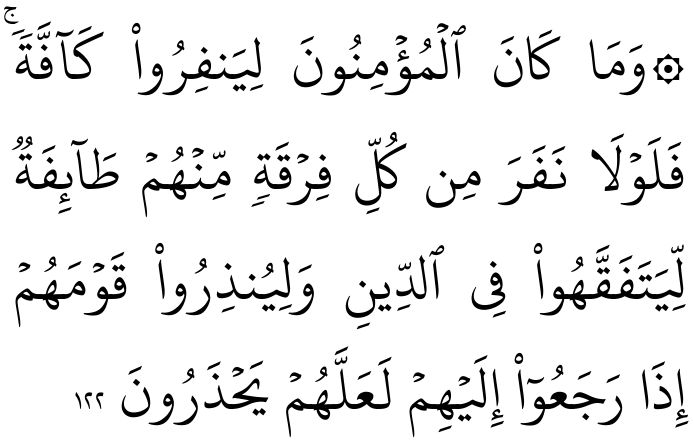

"Tidak sepatutnya bagi mukminin itu pergi semuanya (ke medan perang). Mengapa tidak pergi dari tiap-tiap golongan di antara mereka beberapa orang untuk memperdalam pengetahuan mereka tentang agama dan untuk memberi peringatan kepada kaumnya apabila mereka telah kembali kepadanya, supaya mereka itu dapat menjaga dirinya." 14

${ }^{14}$ QS. At-Taubah: 122 


\section{INTIQAD: JURNAL AGAMA DAN PENDIDIKAN ISLAM}

ISSN 1979-9950 (print) || ISSN 2598-0033 (online), http://jurnal.umsu.ac.id/index.php/intiqad DOI: https://doi.org/10.30596/intiqad.v11i1.3195

Vol. 11, No. 1 (Juni 2019)

Pengetahuan tentang makna pendidikan, beberapa pendapat para ahli memaknai tentang pendidikan, diantaranya adalah;

a. Prof. Dr. H. Haydar Putra Daulay, MA menyebutkan bahwa pada dasarnya pendidikan bertujuan untuk membentuk pribadi muslim seutuhnya, mengembangkan seluruh potensi manusia baik yang berbentuk jasmani maupun rohani, menumbuhsuburkan hubungan yang harmonis setiap pribadi dengan Allah, manusia dan alam semesta. ${ }^{15}$

H. M. Arifin; Pendidikan Islam adalah sebuah proses untuk mengarahkan manusia dalam mengangkat derajat kemanusiaan pada kehidupannya sesuai dengan kemampuan dasar (fithrah) dan kemampuan ajarnya. ${ }^{16}$

b. Muhammad Munir Mursyi; bahwa pendidikan Islam adalah upaya dalam memberikan pendidikan pada fitrah manusia, karena Islam merupakan agama fitrah, maka semua perintah

${ }^{15}$ Haidar Putra Daulay, Pendidikan Islam dalam Sistem Pendidikan Nasional di Indonesia, (Jakarta: Penerbit Kencana, 2004), h. 31

${ }^{16}$ H.M. Arifin, Filsafat Pendidikan Islam, (Jakarta: Bumi Aksara, 1991), cet. Ke-3, h. 7 dan larangan serta kepatuhan untuk mengetahui fitrah ini. ${ }^{17}$

c. Hasan Langgulung; pendidikan Islam adalah sebuah proses spiritual dalam mendidik akhlak, mendidik intelektual dan mendidik sosial dengan berusaha membimbing manusia dan memberi nilai-nilai, prinsip-prinsip dan teladan ideal bagi kehidupan dengan tujuan untuk menghadapi kehidupan dunia dan akhirat. ${ }^{18}$

\section{Ayat-Ayat Alquran Tentang}

\section{Pendidikan Ruhani}

Ada 4 ayat yang penulis sajikan pada makalah ini tentang ayat-ayat Alquran yang berkaitan dengan pendidikan ruhani diantaranya adalah:

Pertama, Alquran surat al-Isra' ayat 85 :

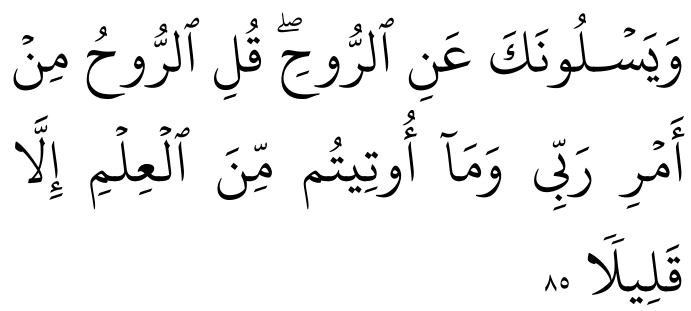

"Dan mereka bertanya kepadamu tentang roh. Katakanlah: "Roh itu

17 Muhammad Munir Mursyi, AlTarbiyah al-Islamiyah, (Cairo: Dar al-Kutub, 1977), h. 25

18 Hasan Langgulung, Asas-Asas Pendidikan Islam, (Jakarta: PT. Pustaka Al Husna Baru, 2003), h. 62 
Vol. 11, No. 1 (Juni 2019)

termasuk urusan Tuhan-ku, dan tidaklah kamu diberi pengetahuan melainkan sedikit".

Asbab turunnya ayat diatas merupakan jawaban bagi kaum musyrikin (ahli kitab) yang mempertanyakan kepada Rasulullah saw tentang ruh yang merupakan perkara ghaib, mereka bertanya, "apakah ruh itu ?", jawaban tersebut tentunya terdapat dalam Alquran yakni konsep yang mengajarkan bahwa sesungguhnya menyikapi masalah tersebut manusia berpikir haruslah sesuai dengan kadar kemampuan akal dan pengertahuan manusia, oleh karenaya tidaklah benar membebani akalnya dengan pemikiranpemikiran diluar kuasa dan kemampuannya. Sayyid Quttub dalam tafsir Tafsir Fi Zilalil Qur'an Jilid 7 menyatakan bahwa sesungguhnya Alquran bukanlah menutup dan melarang manusia untuk berpikir dan berbuat, akan tetapi mengupayakan akal untuk tetap berperan sesuai dengan batas kemampuan dan sesuai dengan ranahranah apa yang harus dan layak untuk dipikirkan dan dipertanyakan.

Sedangkan perkara ruh adalah termasuk perkara-perkara ghaib, abstrak dan rahasia-rahasia Allah swt, karena manusia tidak akan pernah mampu memberi jawaban apa itu ruh, bagaimana datang dan perginya melainkan hanya sekelumit informasi tentang ruh sebagai gambaran dan pelajaran bagi manuisa yang dijelaskan dalam kitab-Nya. ${ }^{19}$

Kedua, Alquran surat al-Anfal ayat 2, yaitu:
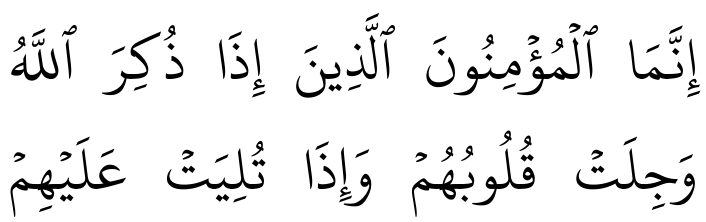

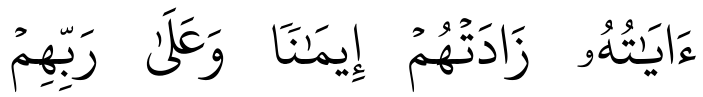

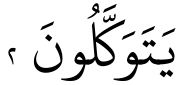

"Sesungguhnya orang-orang yang beriman ialah mereka yang bila disebut nama Allah gemetarlah hati mereka, dan apabila dibacakan ayat-ayat-Nya bertambahlah iman mereka (karenanya), dan hanya kepada Tuhanlah mereka bertawakkal."

Surat al-Anfal ayat 2 tersebut merupakan lanjutan dari ayat sebelumnya yaitu surat al-Anfal ayat 1 dimana pokok permasalahannya adalah telah terjadi selisih pendapat antara kaum mukmin tentang pembagian harta rampasan peran. Surat al-anfal ayat $2 \mathrm{ini}$ menjelaskan tentang sifat-sifat kaum mukmin pada setiap kejadian dan keadaan sebagai penjelasan lanjutan dari

\footnotetext{
${ }^{19}$ Sayyid Quthb, Tafsir Fi Zilalil Quran
} Jilid 7, (Jakarta: Gema Insani, 2003), h. 287. 
ayat sebelumnya yaitu sesungguhnya orang-orang yang beriman ialah mereka yang bila disebut nama Allah gemetarlah hati mereka, dan apabila dibacakan ayatayat-Nya bertambahlah iman mereka (karenanya), dan hanya kepada Tuhanlah mereka bertawakkal.

Penjelasan dari orang-orang mukmin yang terdapat pada ayat tersebut adalah:

1) Orang mukmin akan bergetar hatinya, mantab ruhnya, sehat ruhaninya jika disebut nama Allah karena keagungan dan kekuasaanNya. Mengingat begitu besarnya nikmat dan karunia yang Allah berikan kepada orang mukmin, maka mereka merasa takut jika tidak melaksanakan hak Allah dengan menunaikan kewajibannya sebagai makhluk ciptaan-Nya. Bergetar hati mereka maknanya adalah perumpamaan dari sifat takut tersebut.

2) Orang mukmin jika mendengar dan dibacakan atasnya ayat-ayat Allah maka akan bertambahlah imannya, tenang ruh dan sehat dan kuat ruhaninya karena ayat-ayat Alquran bagi mereka mempunyai pengaruh yang besar bagi jiwa, ruhani dan hati mereka, sehingga bertambah yakin dan kuat iman mereka akan kekuasaan dan kebesaran Allah Swt. Bertambah dan berkurangnya iman seseorang akan nampak terlihat dari perbuatan, tingkah laku dan sikap seseorang.

3) Orang mukmin berserah diri dan tawakkal hanyalah kepada Allah swt semata, jika telah melaksanakan kewajibannya sebagai hamba-Nya, telah memenuhi hak-hak Allah dengan melaksanakan kewajiban dan meninggalkan larangan-Nya, maka ikhtiar seorang mukmin yang terakhir adalah bertawakkal kepada-Nya. Dengan bertawakkal akan mendidik ruhani menjadi tenang mengharap dan bertumpu segalanya hanya kepada Allah Swt semata.

Ketiga, Alquran surat ar-Ra'd ayat 28:

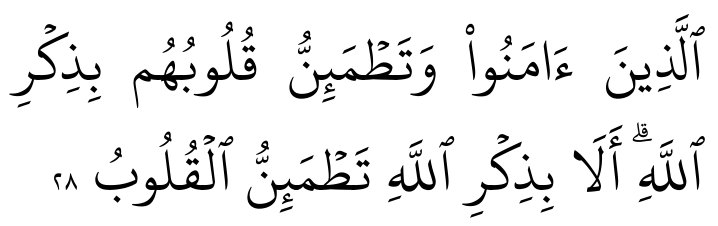

“(yaitu) orang-orang yang beriman dan hati mereka manjadi tenteram dengan 
Vol. 11, No. 1 (Juni 2019)

mengingat Allah. Ingatlah, Hanya dengan mengingati Allah-lah hati menjadi tenteram."

Surat ar-Ra'd ayat 28 tersebut di atas merupakan keterangan tambahan dan jawaban Allah terhadap permintaan orang kafir tentang Alquran adalah mu'jizat nabi Muhammad Saw yang terdapat pada ayat sebelumnya yaitu ayat 26 dan 27, karena mereka mengingkari bahwa Alquran adalah bukti kebenaran dari mu'jizat kenabian. Melalui ayat ini juga penjelasan tentang keadaan orang mukmin yang bertakwa, digambarkan oleh Allah bahwa mereka adalah orangorang yang sedang menuju kepada Allah swt, yang mengaku akan kebesaran-Nya dengan beribadah dan Allah pasti akan membuka hati, ruh dan jiwa mereka sehingga mereka mendapatkan keberuntungan hidup dan keselamatan di dunia dan di akherat. Jika selalu mengingat-Nya maka hati dan ruh tidak akan pernah ragu sedikitpun akan wujudNya, dan sesungguhnya dengan mengingat Allah lah hati dan jiwa akan tenang karena nur dan cahaya Allah selalu bersama dengan mereka. Jika ruhani kenyang dengan "mengingat selalu akan Allah maka cahaya iman akan melimpah kepadanya, dengan cahaya itulah kemudian akan sirna rasa gelisah, sedih dan gundah gulana." 20

Keempat, Alquran surat al-Fajr ayat 27-28;

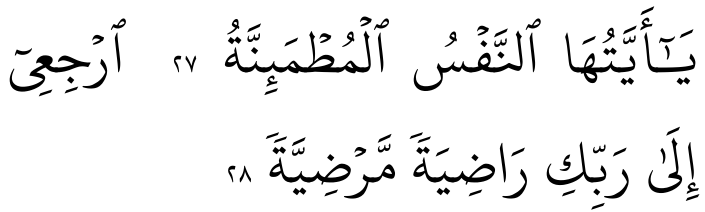

"Hai jiwa yang tenang, Kembalilah kepada Tuhanmu dengan hati yang puas lagi diridhai-Nya."

Ayat di atas menjelaskan bahwa dengan menjaga sikap, menjaga hawa nafsu terhadap ketamakan duniawi meskipun diberi kelapangan rizki maka jiwa akan tenang, ruhani akan sehat dll. Dengan tidak banyak keinginan dunia, maka ruhani cenderung akan bersikap qona'ah, sesungguhnya Allah menjanjikan jika orang-orang yang tidak mengikuti hawa nafsu duniawi maka mereka akan mencapai martabat kesempurnaan. Orang-orang yang hati, jiwa dan ruhaninya seperti itu akan merasa tenang dan aman karena mereka selalu dijaga dan diawasi oleh Allah Swt. mereka hanya akan memprioritaskan perkara-perkara yang bersifat ruhaniah, melupakan kelezatan yang bersifat jasmaniah. "Orang yang semacam ini

${ }^{20}$ Ahmad Mustafa al Maraghi, Tafsir alMaragi Jilid 13, (Semarang: CV. Toha Putra, 1988), h. 174. 
jika dikaruniai kelebihan harta atau lainnya, maka mereka hanya mengambil haknya, selalu bersikap sabar dan tidak meminta-minta kepada yang lain. Allah menjanjikan orang-orang seperti ini akan mendapatkan keridhoan-Nya dan akan berada di sisi-Nya kelak sesuai dengan amal yang mereka lakukan ketika di dunia." $" 21$

\section{Pendidikan Ruhani dalam} Alquran

Diskursus tentang pendidikan ruhani, term ruh dalam Alquran terdapat sedikitnya tidak kurang dari 25 ayat. Ini menyatakan bahwa ruh berasal dari Allah yang ditiupkan kepada manusia sejak umur 120 hari. Dalam hadits yang diriwayatkan oleh Abdullah Ibnu Mas'ud dalam Adz-Dzahabi dapat digambarkan fase-fase peniupan ruh yang dimulai dari masa manusia berada dalam perut ibunya selama 40 hari, kemudian tumbuh menjadi segumpal darah selama 40 hari, 40 hari kemudian menjadi segumpal daging dan kemudian Allah mengutus malaikat untuk meniupkan ruh lalu ditulislah 4 perkara yaitu rezeki, ajal, amal dan nasib celaka

21 Ahmad Mustafa al Maraghi, Tafsir alMaragi Jilid 30, (Semarang: CV. Toha Putra, 1985), h. 259 atau bahagia. $^{22}$ Beberapa pernyataan tentang ruh menurut para ahli kiranya dapat memberi kemudahan dan pemahaman dalam memaknai pendidikan ruhani, berikut pengertian ruh menurut para ahli diantaranya adalah:

1) Ibnul Qoyyim Al-Jauziyah, roh disebut juga dengan (ar-ruh) karena dengannya badan bisa hidup, roh itu mengajak kepada akherat dan mempengaruhinya sedangkan malaikat mengikuti bersama akal dan roh. Allah Swt menolong akal dan roh dengan memberikan ilham dan taufiq (bantuan) kepadanya. Kemudian ada pendapat bahwa roh itu tidak akan mati dan tidak akan fana, pendapat lain bahwa roh itu seperti rupa makhluk punya tangan, kaki, mata, pendengaran, penglihatan dan lidah, kemudian ada yang berpendapat bahwa roh itu adalah kerohanian yang diciptakan dari kerajaan langit, jika ia bersih maka ia akan dikembalikan ke sana. ${ }^{23}$

22 Adz-Dzahabi, Kitab Mu'jam AsSyukhuh, jilid 2, h. 764

${ }^{23}$ Ibnul Qoyyim Al-Jauziyah, Menjelajah Alam Roh, Kupas Tuntas 22 Masalah Roh Disarikan dari Kitab Ar-Ruh ang Steril dari 
2) Umar Muhammad At-Toumy AsySyaibani, bahwa manusia memiliki potensi ruhani yang meliputi badan, akal dan roh, ketiganya persis seperti segitiga yang sisi-sisinya sama panjang. ${ }^{24}$ Pendapat lain bahwa potensi rohani manusia itu meliputi kekuatan yang terdapat di dalam batin manusia yakni akal, kalbu, nafsu, roh dan fitrah.

3) Al-Jurjani menyebutkan bahwa ruh merupakan esensi halus yang dimiliki oleh manusia untuk mengetahui dan memahami dan untuk mengontrol ruh hewani yang bersemayam pada diri manusia itu, dimana akal tidak akan mampu untuk mengetahui hakikat ruh tersebut, boleh jadi ia mengalami pembaharuan atau bisa menjadi tabiat pada tubuh manusia itu sendiri. $^{25}$

4) Kemudian ruh juga bisa dimaknai sebagai penguatan, peneguhan, maunah atau pertolongan yang Allah Swt berikan kepada siapa

Riwayat dan Hikayat Lemah, (Solo: Pustaka Arafah, 2012), h. 209-211

24 Umar Muhammad At-Toumy AsySyaibani, Falsafah at-Tarbiyah al-Islamiyah, (Trabulus: Asy-Syirkah al-Ammah,1975), h. 92 25 Al-Jurjani, At-Ta'rifat, (Mesir: Musthafa al-Halabi, 1938), h.34 yang Ia kehendaki. Sebagaimana firman-Nya dalam surat alMujadilah ayat 22.

Berbicara mengenai karakter pendidikan ruhani, bahwa karakter manusia modern saat ini adalah lebih percaya pada rasionalitas, sains dan teknologi serta menempatkannya sebagai instrumen untuk mengendalikan alam. ${ }^{26}$ Dampak negatif dari pandangan rasionalitas tersebut, pada akhirnya menjadikan worldview manusia modern cenderung menilai segala sesuatu hanya sebatas pandangan empiris dan berdasar pada sudut pandang pinggiran eksistensi. Sementara aspek spiritual atau pusat spiritualitas dirinya terpinggirkan. Maka dari itu, meskipun secara material manusia mengalami kemajuan yang spektakuler secara kuantitatif, namun secara kualitatif dan holistik tujuan hidupnya, manusia mengalami krisis spiritual (ruhani) yang sangat menyedihkan. Sehingga secara langsung membawa dampak yang signifikan terhadap kehidupannya, maka makna kehidupannya telah hilang dan sirna dari dirinya.

${ }^{26}$ Tedi Sutardi, Antropologi: Mengungkap Keragaman Budaya, (Bandung: Setia Putra Inves, $\mathrm{tt})$, h. 69 
Oleh sebab itu semua, maka manusia modern yang hidup pada abad ini tentunya tidaklah membuang dirinya jauh-jauh dari sang maha pemberi hidup yakni Allah Swt. dan untuk mengembalikan diri manusia tersebut yang telah hilang dan sirna karena dampak dari modernitas atau kehidupan modern yang serba instan dan dimanjakan dengan teknologi besutan manusia tersebut, maka salah satu jalan adalah dengan pendekatan pendidikan ruhani agar diri terasa tidak kosong dan hampa. Berikut ada beberapa karakteristik pendidikan ruhani sebagai upaya untuk menyadarkan diri manusia agar kembali menemukan kebahagiaan yang haqiqi pada setiap diri manusia, diantaranya adalah:

\section{a. Salat}

Perintah salat adalah wajib hukumnya bagi yang sudah aqil baligh, banyak ayat Alquran menyebutkan tentang kewajiban mendirikan shalat lima waktu seperti dalam surat alBaqarah ayat 3, al-Baqarah ayat 43, alBaqarah ayat 45 , al-Baqarah ayat 277 , an-Nisa' ayat 102, an-Nisa' ayat 103, alMa'idah ayat 6 , at-taubah ayat 11 , attaubah ayat 54 , al-hud ayat 114 , al-Isra' ayat 78, al-Isra' ayat 79, al-Maryam ayat
59 , at-Thaha ayat 14 , al-hajj ayat 77 , alMu'minun ayat 2, al-Mu'minun ayat 9, al-Ankabut ayat 45, al-ma'arij ayat 23, al-Muzammil ayat 20, al-Mudatsir ayat 42-43, al-Ma'un ayat 4, al-Ma'un ayat 5 dan al-Kautsar ayat 2. Beberapa ayat tersebut memberi penjelasan untuk mendirikan shalat sebagai wujud penghambaan manusia kepada Allah Swt yang menciptakan dan memenuhi segalanya. Bahwa dengan shalat jiwa menjadi sehat, hati menjadi tenang dan shalat sebagai makanan ruhani bagi orang-orang yang beriman.

\section{b. Puasa}

Puasa adalah perintah Allah swt setelah shalat dalam lima rukun Islam, maka tidak sah Islam seseorang jika tidak mengerjakan puasa wajib pada bulan ramadhan. Perintah wajibnya puasa tersebut tentunya memiliki makna dihadapan Allah Swt dan manfaat bagi orang mukmin, diantaranya adalah:

1) Ungkapan rasa syukur manusia atas limpahan nikmat yang Allah Swt berikan kepadanya,

2) Wujud ketaatan dan kepatuhan seorang hamba kepada perintah Allah Swt, kejujuran dan kekuatan ruhani dalam menahan hawa nafsu baik lapar, dahaga dan lainnya, 
3) Puasa sebagai sarana untuk menjaga kesehatan ruhani, jiwa dan raga, melalui pengaturan pola makan, minum dan konsumsi lainnya, karena penyebab segala munculnya penyakit adalah bagaimana pola makan, minum dan konsumsi benda lainnya yang berlebihan,

4) Ibadah puasa membendung dan menahan nafsu syahwat orang beriman, sehingga ruhani, jiwa dan raganya hanya diperuntukkan untuk ibadah kepada Allah swt,

5) Ibadah puasa mendidik orang beriman untuk selalu bersedekah, peduli dengan orang lain yang lebih membutuhkan. ${ }^{27}$

\section{c. Tazkiyatun Nafs}

Manusia terdiri diri dari dua unsur, yaitu unsur yang terdiri dari jasad dan ruh, sehingga manusia merupakan makhluk jasadiyah dan ruhiyah sekaligus. Hubungan keduanya bagaikan hubungan antara seorang nakhoda dengan perahunya, yang mana sang nakhoda berperan sebagai pengarah dan pengatur dalam menenangkan arus air yang membawa perahu tersebut untuk mencapai tujuannya serta menjaganya

27 Tgk. H.Z.A. Syihab, Tuntunan Puasa Praktis, (Jakarta:Bumi Aksara,1995), h. 5-6 ditengah-tengah hempasan gelombang. ${ }^{28}$ Dalam Alquran, "kata al-Nafs digunakan dalam berbagai bentuk dan aneka makna. Kata al-Nafs dijumpai sebanyak 297 kali, masing-masing dalam bentuk mufrad (singular) sebanyak 140 kali, sedangkan dalam bentuk jamak terdapat dua versi, yaitu nufus sebanyak 2 kali dan anfus sebanyak 153 kali dan dalam fi'il ada dua kali. Kata al-nafs dalam Alquran memiliki aneka makna, susunan kalimat, klasifikasi dan objek ayat." ${ }^{29}$ Diantaranya, "Nafs bermakna sebagai diri atau seseorang, seperti yang disebut dalam (QS. ali-Imran: 61), (QS. Yusuf: 54), Nafs sebagai sebagai person sesuatu, terdapat dalam Alquran (QS. Al-Furqan: 3), (QS. al-An'am: 130), Nafs sebagai ruh terdapat dalam (QS. al-An'am 39), Nafs sebagai totalitas manusia terdapat dalam (QS. al-Maidah: 32), (QS. alQashash: 19, 33), Nafs sebagai sisi dalam manusia yang melahirkan berbagai macam tingkahl laku, seperti

28 Ibnu Jauzi, Al-Thibb Al-Ruhi, Tahqiq Abdul Aziz Izzuddin Al-Sairawani, (Damaskus: Dar Al-Anwar, 1993), h. 35-36

29 Baharudin, Paradigma Psikologi islami, (Yogyakarta: Pustaka Pelajar, 2007), h. 95-100 
dalam (QS. al-Ra'd: 11), (QS. al-Anfal: 53). ${ }^{\prime 30}$

Realitas yang mendasari dan prinsip yang menyatukan apa yang kemudian dikenal sebagai manusia bukanlah perubahan jasadnya, melainkan keruhaniannya. Hal itu dikarenakan manusia pada hakikatnya adalah makhluk ruhani, yang esensinya bukanlah fisiknya dan bukan pula fungsi fisik melainkan jiwa (nafs) adalah sesuatu yang mempunyai tempat dan fungsi fisik adalah sesuatu yang tidak berdiri sendiri, keberadaannya tergantung kepada fisik. Dengan demikian, "manusia merupakan substansi imaterial yang berdiri sendiri dan merupakan subyek yang mengetahui." ${ }^{31}$ Substansi imaterial tersebut bisa dibuktikan dengan logika bahwa yang mempunyai kemampuan memahami bukanlah fisik manusia, sebab jika fisik manusia mempunyai kemampuan memahami, maka objekobjek lainnya mesti mempunyai kemampuan memahami juga, tapi kenyataannya tidak demikian, sehingga bisa dikatakan bahwa jiwalah yang

\begin{tabular}{c}
\hline 30 Achmad Mubarak, Jiwa Dalam \\
Alquran, (Jakarta: Paramadina, 2000), h. 44-53 \\
31 Akhmad Alim, Tafsir Pendidikan \\
Islam, (Jakarta: AMP Press, 2014), h. 162
\end{tabular}

mempunyai kemampuan untuk memahami tersebut.

Pendidikan ruhani (tarbiyah ruhiyah) atau dalam istilah modern disebut dengan pendidikan spiritual, pendidikan hati, pendidikan ruhani, kecerdasan ruhiyah, kecerdasan spiritual, kecerdasan emosi, multiple intelligences, manajemen qalbu, dan beragam istilah lainnya. Dari sekian, banyak istilah tersebut, istilah yang tepat untuk pendidikan ruhani adalah tazkiyatun nafs. Hal ini berdasarkan Alquran surat al-Syams ayat 7-10 menyebut makna tazkiyah:
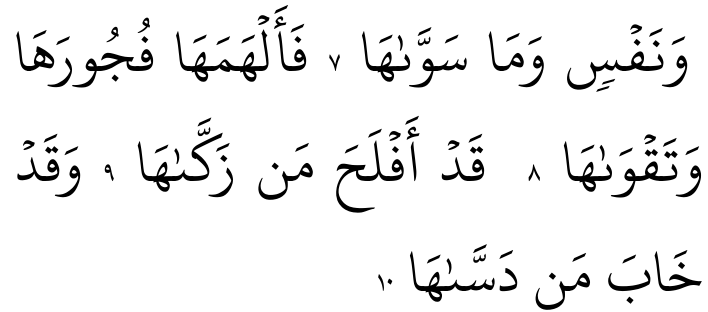

"Dan jiwa serta penyempurnaannya (ciptaannya), Maka Allah mengilhamkan kepada jiwa itu (jalan) kefasikan dan ketakwaannya. Sesungguhnya beruntunglah orang yang mensucikan jiwa itu, Dan Sesungguhnya merugilah orang yang mengotorinya.",32

Jadi pendidikan ruhani adalah merupakan sebuah upaya untuk menyucikan jiwa dari berbagai kecenderungan untuk menyucikan jiwa dari berbagai kecenderungan buruk dan

${ }^{32}$ QS. Al-Syams: 7-10 
dosa, kemudian menghiasinya dengan amal shalih dan sifat-sifat terpuji agar selalu tunduk dan patuh kepada Allah Swt, serta tercapainya derajat ihsan, sehingga terwujudnya akhlak al-karimah dan merasakan pengawasan Allah Swt dimana pun berada.

\section{d. Muraqabah}

Muraqabah adalah pengetahuan hamba secara terus menerus dan keyakinannya bahwa Allah swt mengetahui zhahir dan batinnya. Ia merupakan hasil pengetahuannya bahwa Allah mengawasinya, melihatnya, mendengar perkataannya, mengetahui amalnya di setiap waktu dan dimanapun, mengetahui setiap hembusan napas dan tak sedetik pun lolos dari perhatian-Nya. Kemudian Al-Jauziyah menulis bahwa muraqabah juga merupakan ubudiyah dengan asma'Nya Ar-Raqib, Al-Hafidz, Al-Alim, As-Sami' dan Al-Bashir (Maha Mengawasi, Menjaga, Mengetahui, Mendengar dan Melihat). Siapa yang memahami asma' ini dan beribadah menurut ketentuannya, berarti dia telah sampai ke tingkat muraqbah. ${ }^{33}$

33 Ibnu Qayyim Al-jauziyah, Madarijus Salikin, Pendakian Menuju Allah, (Jakarta: Pustaka Al-Kautsar, 2009), h. 215
Pengarang Manazilu as-Sa’irin, mengatakan, Muraqabah artinya terus menerus menghadirkan hati bersama Allah swt. Ada tiga derajat muraqabah diantaranya yaitu;

1) Muraqabah Allah terhadap perjalanan kepada-Nya secara terus menerus memenuhi hati dengan keagungan Allah Swt, mendekatkan diri kepada-Nya sambil membawa beban dan pembangkit kesenangan.

2) Muraqabah Allah terhadap penolakan penentangan, yaitu dengan berpaling dari bantahan

3) Muraqabah azal untuk menerima panji tauhid dan muraqabah isyarat azal yang muncul di setiap saat dan berlaku untuk selamalamanya. ${ }^{34}$

\section{e. Zikir (Mengingat dan Menyebut} Asma' Allah)

Dalam Alquran surat al-Ahzab: 41 menjelaskan tentang peintah kepada manusia untuk berzikir sebanyakbanyaknya:

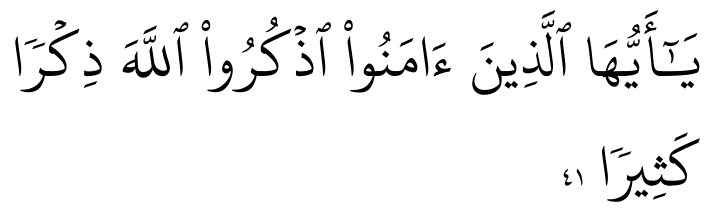

${ }^{34}$ Ibid., h.215-217 
"Hai orang-orang yang beriman, berzdikirlah (dengan menyebut nama) Allah, zikir yang sebanyak-banyaknya" 35

Sebagaimana Ibnu Katsir menafsirkan dan memaknai ayat tersebut, bahwa Allah Swt memerintahkan kepada para hamba-Nya untuk selalu mengingat serta menyebut asma'-Nya karena Allah Swt sudah menganugerahkan banyak nikmat dan Ia juga telah menyiapkan balasan yang besar untuk para hamba yang selalu dan memperbanyak mengingatnya. ${ }^{36}$

Berdasarkan dari ayat tersebut bahwa Allah memberikan perintah kepada hamba-hamba-Nya untuk selalu berzikir dan memperbanyak mengingatNya. Secara bahasa zikir adalah mengingat akan Allah zhahiran wa bathinan artinya menyebut dengan lisannya dan mengingat Allah dalam hatinya. Sedangkan makna secara global zikir adalah segala perbuatan, perkataan dan keyakinan hanyalah ditujukan untuk melaksanakan perintah Allah swt dan menjauhi segala larangan-Nya. Dengan memperbanyak zikir kepada-Nya pada setiap nafas kehidupan jika di niatkan untuk ibadah maka akan diberi ganjaran pahala. Mengingatnya pada setiap keadaan, kapanpun dan dimanapun membuktikan bahwa Allah itu maha kuasa atas segalanya, bahwa setiap hamba dalam setiap detak nafasnya, pekerjaannya, dan istirahatnya harus menyebut dan mengingat nama-Nya agar terlindung dan selamat di dunia dan akherat. Maka, bahwa perbuatan yang paling baik melebihi dari segala perbuatan lainnya adalah dengan zikrullah yaitu senantiasa berzikir kepada Allah Swt, karena zikir meliputi segala amal kebajikan. Rasulullah menegaskan dalam hadis yang diriwayatkan oleh Muslim, bahwa "Rasulullah Saw bersabda: Maukah kalian aku beritahu tentang amal yang paling baik dan paling suci di sisi Tuhanmu dan paling tinggi derajatnya serta lebih dari bersedekah dengan emas dan perak atau berjihad di jalan Allah sehingga kamu memenggal leher musuhmu atau mereka memenggal lehermu. Para sahabat bertanya kepada Rasulullah Saw: amal apakah itu wahai Rasulullah Saw? Beliau bersabda, "menyebut dan mengingat Allah Swt.",37

\footnotetext{
${ }^{37}$ Ahmad Bin Hanbal, Musnad juz.5,
} (Cairo: Dar al-Kutub al-Ilmiah, 1995), h.195 
Hakikat daripada zikir yaitu melupakan segala sesuatu yang ada di dunia fana ini dan hanyalah mengingat akan Allah Swt semata. Dzunnun alMishri dalam al-Qusyairi ${ }^{38}$ menjelaskan bahwa Allah Swt jauh lebih penting dan berharga daripada alam beserta isinya yang diciptakan-Nya ini karena semuanya adalah bathil atau tiada. Makna bathil atau tiada maksudnya adalah karena alam ini diciptakan dari ketiadaan menjadi ada, sehingga kemudian tidak mungkin manusia lebih mengejar sesuatu yang tiada (bathil) dari pada yang hak yaitu Allah Swt. sedangkan Rasulullah Saw sendiri selalu mengingat akan Allah Swt pada setiap keadaan hingga pada saat tidur beliau selalu mengingat akan Allah Swt.

\section{f. Ikhlas}

Jiwa tidak akan pernah lepas dari tipu daya syetan kecuali dengan ikhlas. Allah Swt berfirman, "Iblis menjawab, Demi kekuasaan Engkau, aku akan menyesatkan mereka semua kecuali hamba-hamba-Mu yang mukhlis diantara mereka."39 Ikhlas juga bermakna menghilangkan pandangan Islam akan keikhlasan itu sendiri, karena

\footnotetext{
${ }^{38}$ Al-Qusyairi, ar-Risalah al-Qusyairiyah, (Beirut: Darul Khair, 1995), h. 222

${ }^{39}$ QS. Al-Shaad: 82-83
}

orang yang merasa di dalam ikhlasnya terdapat keikhlasan, maka keikhlasannya tersebut masih membutuhkan keikhlasan lagi. Mengutip dalam buku "Hati yang Bening" oleh Said Abdul Azhim Fudhail berkata, "mengerjakankan suatu amal karena orang lain adalah riya' sedangkan beramal karena orang lain adalah syirik."40 Dengan ikhlas Allah mengampuni keduanya. Oleh karena itu, perbuatan dan diamnya dari amalan tersebut hendaklah dilakukan sematamata karena Allah Swt. karena surga dan neraka berada pada genggaman-Nya.

Kemudian dimana tempat persinggahan ikhlas itu, muncul pertanyaan. Allah berfirman dalam Alquran surat al-Bayyinah ayat 5, yaitu: "padahal mereka tidak disuruh kecuali menyembah Allah dengan memurnikan ketaatan kepada-Nya dalam (menjalankan) agama dengan lurus ${ }^{41}$."

Kemudian dalam surat an-Nisa' ayat 125, "Dan, siapakah yang lebih baik agamanya daripada orang yang ikhlas menyerahkan dirinya kepada Allah, sedang dia pun mengerjakan kebaikan."42 Menyerahkan diri kepada

40 Said Abdul Halim, Hati yang Bening, (Jakarta: Cendekia Sentra Muslim, 2005), h.181

${ }^{41}$ QS. Al-Bayyinah: 5

${ }^{42}$ QS. An-Nisa': 125 
Vol. 11, No. 1 (Juni 2019)

Allah artinya memurnikan tujuan dan amal karena Allah. Sedangkan mengerjakan kebaikan adalah mengikuti Rasulullah Saw dan sunnahnya. ${ }^{43}$ Kemudian Al-Fudhail berkata, "Maksud yang lebih baik amalnya dalam surat alMulk ayat 2 adalah yang paling ikhlas dan paling benar." Kemudian orangorang bertanya, "wahai Abu Ali, apakah amal yang paling ikhlas dan paling benar itu.” Dia menjawab, "sesungguhnya jika amal itu ikhlas namun tidak benar, maka ia tidak akan diterima. Jika amal itu benar namun tidak ikhlas, maka ia tidak akan diterima, hingga amal itu ikhlas dan benar. Yang ikhlas ialah yang dikerjakan karena Allah dan yang benar ialah yang dikerjakan menurut as-Sunnah. ${ }^{44}$

Banyak yang memberikan defenisi tentang ikhlas, ada yang berpendapat ikhlas adalah menyendirikan Allah sebagai tujuan dalam ketaatan. Kemudian pendapat lain ada yang menyebutkan ikhlas adalah membersihkan perbuatan dari perhatian makhluk. Lalu pendapat lain juga menyatakan ikhlas yaitu menyelaraskan amal secara zhahir dan bathin sehingga

43 Ibnu Qayyim Al-jauziyah, Madarijus Salikin, Pendakian Menuju Allah, (Jakarta: Pustaka Al-Kautsar, 2009), h. 225

${ }^{4}$ Ibid. barang siapa yang mempersaksikan adanya ikhlas dalam ikhlas, berarti ikhlasnya membutuhkan ikhlas lagi, kekurangan oran yang mukhlis dalam ikhlasnya tergantung dari pandangan terhadap ikhlasnya. Jika dia tidak lagi melihat ikhlasnya, maka dialah orang yang benar-benar mukhlis. ${ }^{45}$

Maka oleh karena itu, keikhlasan dalam bersikap, berbuat dan melakukan dalam mendidik, mengajar dan memberi tauladan yang baik merupakan salah satu The way atau jalan dalam bingkai pendidikan ruhani. Kebaikan-kebaikan yang keluar dari jiwa atau hati atau ruh itu hanya berasal dari Allah Swt dan bukan berasal dari manusia itu sendiri, sebagaimana firman-Nya:

"Sekiranya tidak karena Allah dan rahmat-Nya kepada kamu sekalian, niscaya tidak seorang pun dari kalian bersih (dari perbuatan-perbuatan keji dan mungkar) selama-lamanya, tetapi Allah membersihkan siapa yang dikehendaki-Nya."

\section{E. Simpulan}

Pendidikan ruhani pada hakikatnya adalah proses pendekatan dan penguatan hubungan diri manusia sebagai hamba dengan Tuhan sebagai pencipta dengan

\footnotetext{
${ }^{45}$ Ibid., h. 227

${ }^{46}$ QS. an-Nur: 21
} 
cara mengintensifkan hubungan melalui ibadah sehingga terjalin hubungan yang baik dan erat dengan-Nya. Alquran melalui ayat-ayatnya memberikan pengetahuan, pandangan dan cara untuk mempertautkan hubungan manusia dengan Tuhan sang pencipta melalui pendekatan ruhani. Tidak kurang dari 25 ayat dalam Alquran menjelaskan tentang ruhani atau ruh sebagai entitas utama agar manusia dapat hidup. Ruh merupakan sumber kehidupan manusia yang Allah titipkan sementara kepada manusia. Oleh karenanya, ruh tersebut harus diberi suplemen pendidikan agar tetap pada posisi fitrahnya yaitu hanya untuk ibadah dan berbuat baik kepada Allha Swt.

$$
\text { Menjawab pertanyaan pada }
$$
makalah ini tentang apa itu pengertian pendidikan ruhani, apa saja ayat-ayat Alquran tentang pendidikan ruhani dan apa saja karakter pendidikan ruhani dalam Alquran. Paparan pada tulisan diatas, dapat dijelaskan bahwa pendidikan ruhani adalah pendidikan yang mempererat dan menguatkan jalinan hubungan manusia kepada Allah swt melalui giat dalam beribadah secara kontinyu sehingga terbagun hubungan baik dengan-Nya. Adapun ayat-ayat yang menjelaskan tentang pendidikan ruhani diantaranya adalah Alquran surat al-isra' ayat 85, Alquran surat al-Anfal ayat 2, Alquran surat ar-Ra'd ayat 28, Alquran surat al-Fajr ayat 27-28. Selanjutnya indikator pendidikan ruhani untuk mendekatkan diri kepada Tuhan diantaranya adalah melalui pelaksanaan ibadah yang secara terus menerus sesuai dengan perintah-Nya yaitu dengan upaya selalu melakukan shalat, puasa, zikir, muroqobah, tazkiyah dan ridha terhadap qadha dan qadar Allah Swt.

\section{Daftar Pustaka}

Abdul Halim, Said. (2005). Hati yang Bening, Jakarta: Cendekia Sentra Muslim.

Adz-Dzahabi. Kitab Mu'jam AsSyukhuh.

Ahmad Bin Hanbal. (1995). Musnad juz.5, Cairo: Dar al-Kutub alIlmiah.

Alim, Akhmad. (2014). Tafsir Pendidikan Islam, Jakarta: AMP Press.

Al-jauziyah, Ibnu Qayyim. (2009). Madarijus Salikin, Pendakian Menuju Allah, Jakarta: Pustaka AlKautsar. 


\section{INTIQAD: JURNAL AGAMA DAN PENDIDIKAN ISLAM}

ISSN 1979-9950 (print) || ISSN 2598-0033 (online), http://jurnal.umsu.ac.id/index.php/intiqad DOI: https://doi.org/10.30596/intiqad.v11i1.3195

Vol. 11, No. 1 (Juni 2019)

Al-Jauziyah, Ibnul Qoyyim. (2012). Menjelajah Alam Roh, Kupas Tuntas 22 Masalah Roh Disarikan dari Kitab Ar-Ruh ang Steril dari Riwayat dan Hikayat Lemah, Solo: Pustaka Arafah.

Al-Jauziyah, Ibnu Qayyim. (1993). AlThibb Al-Ruhi, Tahqiq Abdul Aziz Izzuddin Al-Sairawani, Damaskus: Dar Al-Anwar.

Al-Qusyairi. (1995). ar-Risalah alQusyairiyah, Beirut: Darul Khair.

Al-Jurjani. (1938). At-Ta`rifat, Mesir:

Musthafa al-Halabi.

Ali, Mohammad Daud. (1998). Pendidikan Agama Islam, Jakarta: PT. Raja Grafindo Persada.

At-Toumy Asy-Syaibani, Umar

Muhammad. (1975). Falsafah at-

Tarbiyah al-Islamiyah, Trabulus: Asy-Syirkah al-Ammah.

Baharudin. (2007). Paradigma Psikologi

Islami, Yogyakarta: Pustaka Pelajar.

Cholil, Adam. (2014). Dahsyatnya Alquran, Alquranul Karim Menjadi Petunjuk dan Solusi Bagi Umat Manusia dalam Mengarungi Samudera Kehidupan, Jakarta: AMP Press.
H.M, Arifin. (1991). Filsafat Pendidikan Islam, Jakarta: Bumi Aksara.

Jalaludin. (2003). Teologi Pendidikan, Jakarta: PT. Raja Grafindo Persada.

Langgulung, Hasan. (2003). Asas-Asas

Pendidikan Islam, Jakarta: PT. Pustaka Al Husna Baru

Mustafa al Maraghi, Ahmad. (1988).

Tafsir al-Maragi Jilid 13, Semarang: CV. Toha Putra.

Mustafa al Maraghi, Ahmad. (1985). Tafsir al-Maragi Jilid 30, Semarang: CV. Toha Putra.

Mubarak, Achmad. (2000). Jiwa Dalam Alquran, Jakarta: Paramadina.

Mursyi, Muhammad Munir. (1977). AlTarbiyah al-Islamiyah, Cairo: Dar al-Kutub.

Putra Daulay, Haidar. (2004), Pendidikan Islam dalam Sistem Pendidikan Nasional di Indonesia, Jakarta: Penerbit Kencana.

Sayyid Quthb. (2003). Tafsir Fi Zilalil Qur'an Jilid 7, Jakarta: Gema Insani.

Sutardi, Tedi. (tt). Antropologi: Mengungkap Keragaman Budaya, Bandung: Setia Putra Inves. 
INTIQAD: JURNAL AGAMA DAN PENDIDIKAN ISLAM

ISSN 1979-9950 (print) || ISSN 2598-0033 (online), http://jurnal.umsu.ac.id/index.php/intiqad DOI: https://doi.org/10.30596/intiqad.v11i1.3195

Vol. 11, No. 1 (Juni 2019)

Tgk. H.Z.A. Syihab. (1995). Tuntunan

Puasa Praktis, Jakarta: Bumi

Aksara.

Zaini, Syahminan. (1991). Hakikat

Agama dalam Kehidupan

Manusia, Surabaya: Al-Ikhlas. 